\title{
Problems and Prospects for the Development of the UK Banking System in the Process of New Industrialization and Digitalization
}

\author{
Olga Sokolova, Nadezhda Goncharova*, and Pavel Letov \\ Ural State University of Economics, 620144 Yekaterinburg, Russia
}

\begin{abstract}
The gist of this article boils down to the development of British banking system in the conditions of new industrialization and digitalization. The banking system of Great Britain is characterized by a high degree of concentration and specialization of banking, a well-developed banking infrastructure, and a close connection with the international loan capital market. London is the world's oldest financial center. The English banking system has the world's widest network of overseas branches. The UK banking system is relatively independent from the credit systems of the European Union. Nevertheless, banking legislation is focused on the unification of banking law within the European Community and supervision of banking activities. In the context of the global financial crisis, the UK banking system, as in other countries, has been severely tested. The most important trend in the development of the UK banking system is the blurring of boundaries between certain types of credit institutions. The subject of the research is the UK banking system in the context of new industrialization and digitalization.
\end{abstract}

\section{Introduction}

Monetary circulation, as the movement of money in cash and non-cash forms, associated with the purchase and sale of goods, as well as payment for services and works, appeared a long time ago [1-10]. Today, the functioning of any economic system is not possible without a competent organization of monetary circulation. The functioning of monetary circulation ensures economic growth, and, accordingly, an increase in the well-being of the population of each individual country [11].

Speaking about money circulation, it is quite fair to touch upon the banking system, the functioning of which is closely related to the use of money. The banking system acts as a kind of employer for all types of money, since it is credit relations that allow economic entities to efficiently use funds. The banking system contributes to the accumulation of free funds and savings of economic entities, which, accordingly, leads to their efficient use and development of the economy.

\footnotetext{
${ }^{*}$ Corresponding author: nadin1325x@yandex.ru
} 
The banking system acts as a kind of employer for all types of money, since it is credit relations that allow economic entities to efficiently use funds. The banking system contributes to the accumulation of free funds and savings of economic entities, which, accordingly, leads to their efficient use and development of the economy.

The purpose of this study is to analyze the principles of the functioning of the UK banking system in the context of new industrialization and digitalization, to identify problems and prospects for the development of the UK banking system.

To achieve this goal, it is necessary to solve the following tasks:

- to consider and analyze the nature of the functioning of British banks and the procedure for their interaction with the banking system of the Eurozone;

- study and analyze the principles of activities of non-bank credit institutions in the $\mathrm{UK}$;

- $\quad$ to identify the problems and prospects for the development of the UK banking system.

- The subject of the research is the UK banking system in the context of new industrialization and digitalization.

\section{Materials and Methods}

The methodological basis of the study is the UK regulatory legal acts governing the organization of monetary circulation and the banking system of the United Kingdom, research materials of reputable economists on the banking system of Great Britain and the Bank of England activities.

The research base consists of legislative and other normative legal acts, textbooks, teaching aids and other theoretical materials by various authors about the peculiarities of monetary circulation and the banking system of modern Great Britain, as well as statistical and other materials.

\section{Results and Discussion}

The UK banking system is one of the most developed banking systems in the world. In order to stabilize the British national economy, the government has set a key economic task - to ensure the stabilization of certain parts of the financial system. The Bank of England, as the main macroeconomic regulator, is called upon to ensure that this task is fulfilled [12].

In the context of new industrialization and digitalization, the Bank of England has been entrusted with responsibilities for regulation and control in the banking sector. It is the settlement bank for the government and other government agencies.

In addition to implementing a number of monetary policy measures such as quantitative easing and the asset purchase mechanism (the Bank of England electronically creates new money and uses it to buy gold from private investors, acquires financial assets such as foreign exchange reserves and corporate bonds to stimulate economic activity and bring inflation back to target), the Monetary Policy Committee is tasked with setting the official bank rate. This concerns the Bank of England's own market transactions with financial institutions, that is, the rate at which it will issue short-term loans to banks and other financial institutions. Changes in the official bank rate certainly tend to affect the full range of interest rates set by commercial banks, building societies and other financial institutions for their own depositors and borrowers.

The UK banking system is one of the oldest in the world and has a three-tier structure (Fig. 2): 
- at the first level is the Bank of England, the main objectives of which are to support the national currency exchange rate, ensure the stability and competitiveness of the financial system;

- the second level is occupied by specialized commercial banks under the control of both residents and non-residents, and by securities accounting companies;

- the third level is represented by construction companies and credit unions.

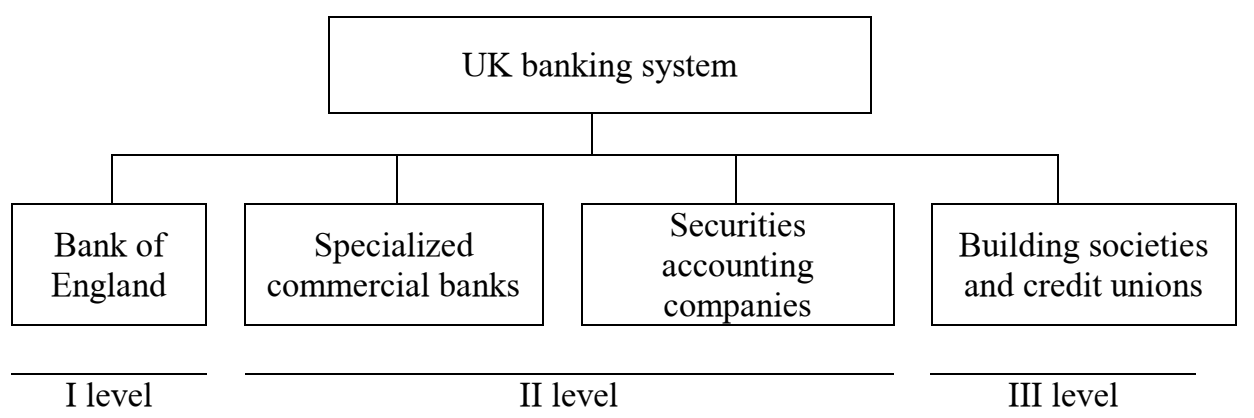

Fig. 1. UK banking system.

The banking system of Great Britain is characterized by a high degree of concentration and centralization, a good level of development of the banking infrastructure and a close connection with the international loan capital market.

Like any banking system, the British one has a number of problems that the state has to solve by analyzing the historical specifics and modern trends.

One of the key problems in the UK banking system is inflation. Inflation is a measure of how much the prices of goods and services have risen over time.

People usually measure inflation by comparing the value of things today with what they were worth a year ago. Average price increases are known as inflation rates.

So if inflation is $3 \%$, it means prices are $3 \%$ higher (on average) than they were a year ago.

Every month the UK Office for National Statistics (ONS) collects about 180,000 prices for about 700 items. The authorities use this "shopping basket" to develop the consumer price index (CPI) [13].

To keep inflation low and stable, the government set an inflation target of $2 \%$ for the Bank of England. It helps everyone to plan their future. Today the inflation rate in the UK is $1.5 \%$.

If inflation is too high or it fluctuates a lot, then it is difficult for businesses to set the right prices, and it is difficult for people to plan their expenses.

But if inflation is too low or negative, then people start to postpone spending because they expect prices to fall. While lower prices sound good, if everyone cuts down on their expenses, companies can fail and people start to lose their jobs.

If the UK banking system misses the inflation target by more than 1 percentage point on either side of the target, the Bank of England must report to the government why this happened (Fig. 2). 


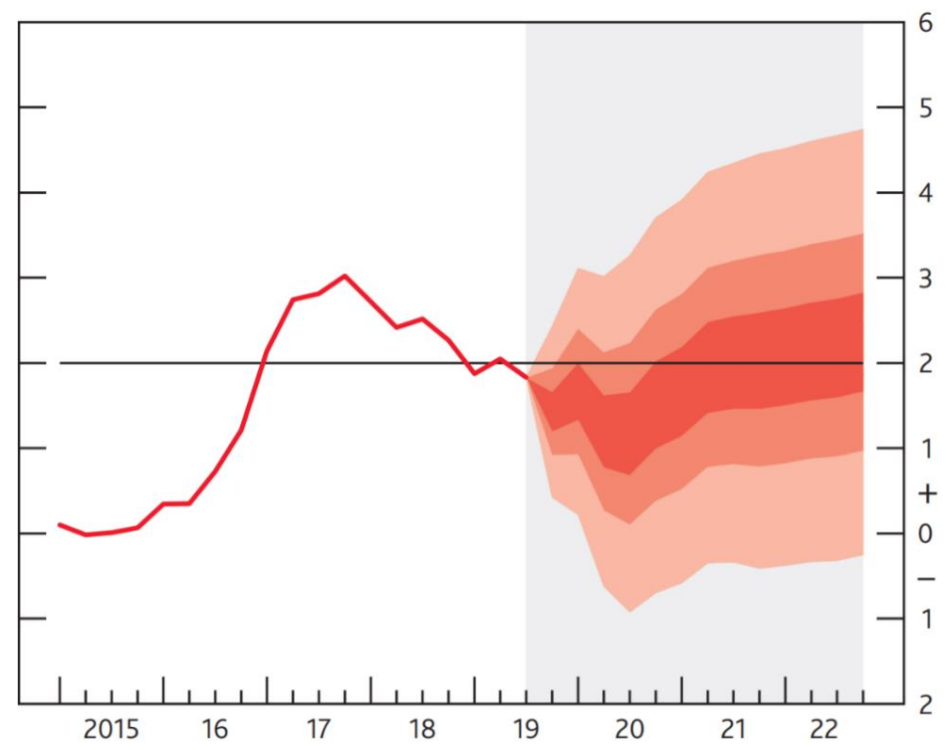

Fig. 2. Inflation values for the period 2015-2019 and the forecast of the Bank of England until 2022.

To keep the inflation rate within the required limits, the Bank of England's Monetary Policy Committee is pursuing a quantitative easing policy. Quantitative easing does not include "turning on the printing presses" and filling the economy with more banknotes, as it sometimes appears. This would most likely lead to uncontrolled inflation. The long-term inflation target is expected to be within the target.

Another important issue is the regulation and supervision of financial firms. The Bank of England regulates and oversees certain types of financial firms and the financial market infrastructure that provides functions critical to the UK financial system, such as payment systems and clearing houses.

The prudential regulator regulates and supervises the activities of about 1,500 banks, building societies, credit unions, insurance companies and large investment companies.

The Authority has three main objectives:

- improving the security of firms controlled by the Authority;

- providing an appropriate degree of protection for insurance policy holders;

- promoting effective competition between firms [14].

The Bank of England is especially concerned about the potential damage firms can do to financial stability. A stable financial system is one in which firms continue to provide essential services to households and businesses.

The Bank of England uses two key instruments to achieve these goals: regulation and supervision. Through regulation, it sets standards or policies that define the expectations of firms. Through supervision, he assesses whether firms meet his expectations, the risks that firms pose to the Bank's objectives, and, when necessary, takes action to mitigate these risks.

The Bank Rate is the single most important interest rate in the UK. It is sometimes referred to as the "Bank of England base rate" or simply "interest rate". Like any other key instrument, the bank rate is experiencing certain problems.

The Monetary Policy Committee sets the bank rate. This is part of the monetary policy measures that the Bank of England is taking to achieve the goal the government has set for it to keep inflation low and stable.

The Bank Rate is the interest rate that the Bank of England pays to the commercial banks that hold funds in the Bank's accounts. This affects the rates these banks charge people to borrow money or pay for their savings. 
If the bank rate changes, then usually the banks change their interest rates on savings and loans. But the bank rate is not the only thing that affects the interest rates on savings and loans.

Interest rates are subject to change for other reasons and may not change by the same amount as the change in the bank rate. To cover their costs, banks must pay less on deposits than they charge when lending. But they cannot pay less than $0 \%$ on deposits.

A change in the banking rate affects how much money the population spends, and how much people spend in general affects the final cost of goods and services. Consequently, a change in the bank rate directly affects the change in prices and the rate of inflation.

Today the UK bank rate is set at $0.75 \%$ (Fig. 3).

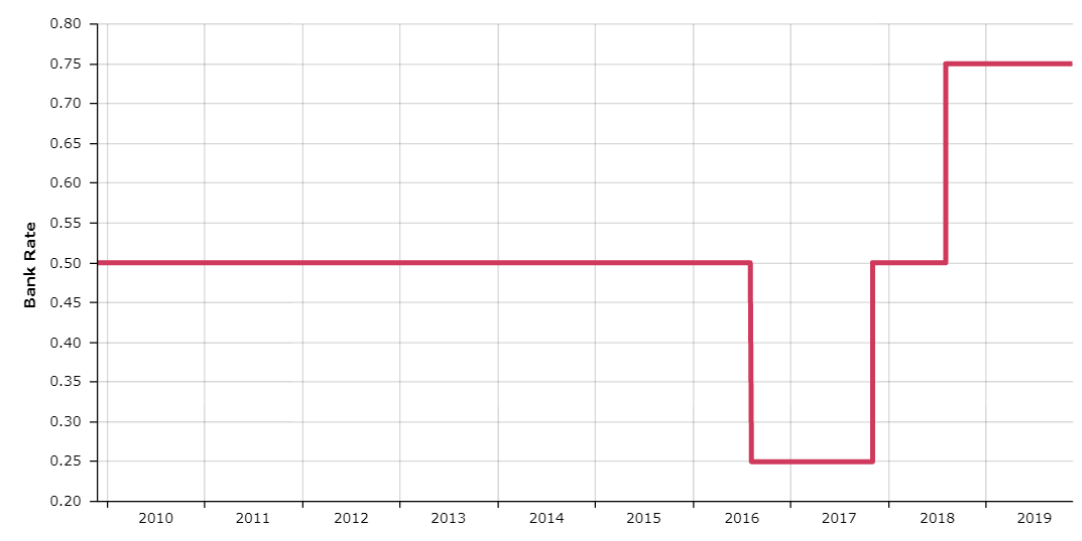

Fig. 3. Banking rate in the UK in 2010-2019.

During the 2008 financial crisis, people cut their spending and many lost their jobs. The Bank of England had to cut interest rates to really low levels to spur spending and create jobs.

In the past few years, the UK economy has needed interest rates to stay very low as the UK recovers from the global financial crisis. But that has changed and the Bank of England recently raised interest rates.

It should be noted that the UK's exit from the European Union (Brexit) will have a moderate negative impact on the country's creditworthiness [15].

According to economists, Brexit will lead to sluggish growth of British companies in the medium term, lower investment and uncertainty about future trade agreements between the British and other countries.

Among the consequences of Brexit, the agency also highlights the negative impact on the UK banking sector, since its business may move to the European Union, the possible failure to conclude a number of future trade agreements, as well as higher import costs and pressure on the country's exports [4].

The main problems and promising directions for the development of the UK banking system are set out in the Financial Stability Strategy developed by the Bank of England.

The Bank of England is confident that the state's economy is healthy only when the population trusts financial institutions, markets and infrastructure. The regulator plays a key role in maintaining financial stability through a number of key policies and mechanisms. The Bank of England sets its own strategy for maintaining financial stability at least once every three years.

The purpose of the Bank of England's financial stability Strategy is to protect and strengthen the stability of the UK's financial system. Added by Parliament in the Bank of England act 1998. In accordance with the law, the Bank's Board of Directors is required to determine the Bank's strategy for this goal and review it at least once every three years. The 
Council delegated the review of the strategy to the financial policy Committee, as required by law, but the Council is ultimately responsible for the strategy.

Financial stability is the consistent delivery of vital services that the real economy requires from the financial system (which includes financial institutions, markets, and market infrastructure). These services include:

- providing the main payment mechanism for goods, services and financial assets;

- mediation between depositors and borrowers and channeling savings into investments through debt and equity instruments;

- risk insurance and diversification.

The Bank of England's financial stability strategy consists of a list of key elements for the entire financial system (Table 1)

Table 1. Bank of England financial stability strategy.

\begin{tabular}{|c|c|}
\hline $\begin{array}{c}\text { Financial stability strategy } \\
\text { element }\end{array}$ & Bank of England Objectives for Financial Stability \\
\hline \multirow{2}{*}{$\begin{array}{l}\text { Setting a strict resilience } \\
\text { baseline to protect the UK's } \\
\text { real economy }\end{array}$} & Implementing strong prudent regulation in the UK financial system \\
\hline & $\begin{array}{l}\text { Working with international bodies to develop rigorous common } \\
\text { international basic standards } \\
\text { Supervising firms to ensure their safety and resilience to prudential and } \\
\text { operational risks (including cyber risk) and, in the case of insurers, also } \\
\text { to protect policyholders } \\
\text { Increasing individual responsibility in financial services } \\
\text { Removing incentives to over-take risks and introducing market discipline } \\
\text { to eliminate the problem of financial companies that are "too big to fail" } \\
\text { Providing infrastructure for flexible settlement of the most important } \\
\text { high value sterling payments in the economy and the most important } \\
\text { retail payment systems }\end{array}$ \\
\hline $\begin{array}{l}\text { Ensuring the adaptation of the } \\
\text { level of resilience to possible } \\
\text { shocks that the system may } \\
\text { face }\end{array}$ & $\begin{array}{l}\text { Identification of potential risks to financial stability and their public } \\
\text { explanation } \\
\text { Stress testing of the state of the banking system on a regular basis to } \\
\text { assess its resistance to developing risks } \\
\text { Taking action, where necessary, to mitigate risks to financial stability } \\
\text { associated with very high private sector debt levels, which could make } \\
\text { the system less resilient and economic growth more fragile } \\
\text { Drafting changes to UK legislation where necessary to ensure the system } \\
\text { is resilient to risks }\end{array}$ \\
\hline $\begin{array}{l}\text { Enabling the system to cope } \\
\text { with shocks if / when they } \\
\text { occur so that it can continue to } \\
\text { support the economy }\end{array}$ & $\begin{array}{l}\text { Building resilience during shocks } \\
\text { Providing liquidity to the UK financial system to mitigate the impact of } \\
\text { shocks } \\
\text { Using problem-solving powers to manage failures of individual banks, } \\
\text { building societies, central counterparties and some investment firms to } \\
\text { mitigate serious disruptions to the financial system and the economy as a } \\
\text { whole }\end{array}$ \\
\hline
\end{tabular}

Thus, considering the problems and promising directions for the development of the banking system of Great Britain, it should be concluded that despite the existence of a spectrum of different problems, the banking system of the United Kingdom still remains one of the most stable in the world. The problems that the Bank of England, regulatory bodies and other participants in the banking system will have to solve in the coming years are unlikely to cause significant harm to the development of the country's financial system as a whole. 


\section{Conclusion}

Summing up, it should be noted that London is the world's oldest financial center. There are more foreign banks working here than English banks, primarily American and Japanese. The share of foreign currency deposits in UK banks is significantly higher than in other countries. The banking system of the United Kingdom has the world's largest network of foreign branches.

The banking system is also characterized by a high degree of concentration and specialization of banking activities, developed banking infrastructure, and close connection with the international loan capital market.

The UK banking system is relatively independent from the credit systems of the European Union. Nevertheless, banking legislation is focused on the unification of banking law within the European Community and supervision of banking activities.

In the context of the global financial crisis, the UK banking system, as in other countries, has been severely tested.

The most important trend in the development of the UK banking system is the blurring of boundaries between certain types of credit institutions.

Today, the Bank of England is undergoing major financial and economic changes that require new approaches to adapt to changing conditions. This requires significant changes in its functions, organization and technology, as well as a completely new approach to interbank and international cooperation.

The consolidation of financial institutions and their universalization have raised serious questions for regulators. On the one hand, they need to provide the so-called "sports field", i.e. traditional competitive equality for all banks and financial market participants, and on the other hand, proper control over intermediary and risky operations that pose the greatest threat to the stability of the financial system as a whole.

It is quite difficult to do this, since the previously existing control system focused on the specialization of institutions operating in the financial market, and organized in this way at the institutional level, today in a number of cases turns out to be ineffective and requires adjustment.

The banking system of Great Britain, unlike most other countries, is practically inseparable from the country's financial system as a whole. There is also a historical explanation for the absence of the definition of "bank" in the country's financial legislation until 1979. The definition that appeared later is unique in its brevity and enables the Bank of England to independently determine which financial institution is a bank and which is not.

The wide scale of the criminal business, inherent in the UK, has forced banks to provide information on suspicious transactions to a special national service. Thus, the UK does not lag behind other countries that have entered the fight against illegal business.

\section{References}

1. A. Grossmann, L. Mooney and M. Dugan, JBR, 95, 232 (2018)

2. C. Pinho, M. Franco, L. Mendes, IJIM, 41, 80 (2018)

3. E. İ. İşeri, K. Uyar, Ü. İlhan, PCS, 120, 967 (2017)

4. F. Castellacci, V. Tveito, RP, 47, 308 (2018)

5. G. R. Laczniak, P. E. Murphy, JBR (2018)

6. L. Brennan, V. N. Lu and T. Heidt, AMJ, 26, 65 (2018)

7. N. A. Goncharova, I. S. Kondratenko, E. N. Zamaraeva, JSSR, 4, 470 (2018)

8. N. A. Goncharova, T. Zh. Solosichenko, N. V. Merzlyakova, IJSCM, 8, 815 (2019) 
9. N. Pisani, A. Kourula, A. K. and R. Meijer, JWB, 52, 591 (2017)

10. P. K. Kannan, A. L. Hongshuang, IJRM, 34, 22 (2017)

11. A.A. Sitnik, LR, 2, 166 (2017)

12. L.R. Gubaidullina, N.A. Goncharova, SMEJ "Concept", 39, 2001 (2017)

13. Bank of England, https://www.bankofengland.co.uk

14. E.V. Vasilyeva, BES, 1, 304 (2018)

15. S.V. Anureev, FA: P\&S, 10, 128 (2017) 